\title{
Using macro cross-border trade data to better understand micro-level country of origin effects
}

\author{
Yener Kandogan $(1)$
}

School of Management, University of Michigan-Flint, Flint, Michigan

\section{Correspondence}

Yener Kandogan, School of Management, University of Michigan-Flint, 303 E. Kearsley, Flint, MI 48503.

Email: yener@umich.edu

\begin{abstract}
The article adapts an estimation methodology from the border effects literature to reveal consumer ethnocentrism versus cosmopolitanism in each country, and animosity versus nostalgia between country pairs. The measurements rely on actual macro cross-border trade data rather than individual purchase intentions typically used in the international marketing literature. The results from early 2010s suggest that purchasing intentions against imports found in this literature do not necessarily translate into actual consumption behavior in international trade. It is quite possible that the consumers are unable to assess country of origin of production despite growing ethnocentrism, and base their actual purchases on perceived origin of product brands. Specifically, it is found that most countries are cosmopolitan rather than ethnocentric, particularly developed countries, favoring any foreign product over domestic products. Most countries also have nostalgic purchasing behavior from specific trade partners with historical linkages. Outside the specific traditional animosities between a country pair, a developed country is relatively less open to imports from another developed trade partner, while an emerging country welcomes it more especially from another emerging trade partner.
\end{abstract}

\section{KEYWORDS}

animosity, cosmopolitanism, country of origin effects, ethnocentrism, nostalgia

\section{1 | INTRODUCTION}

During the post-World War II period, consumers were increasingly exposed to foreign brands as a consequence of marketplace globalization (Diamantopoulos, Florack, Halkias, \& Palcu, 2017). In opposing this trend, nationalism has been on the rise in several countries in recent decades and emerged as one of the important issues facing the multinational companies (Smith, 1992). With increasing loyalty to the nation-state, insecurities about globalization has grown among the populace (Alden, Steenkamp, \& Batra, 2006; Balanabis, Diamantopoulos, Mueller, \& Melewar, 2001; Carvalho, Luna, \& Goldsmith, 2019). As a result, consumers may be turning to domestically made products and/or local brands. The global financial crisis in 2008 exacerbated these ethnocentric tendencies among consumers (Balanabis \& Siamagka, 2017). Consequently, recent elections in many developed countries brought about governments with protectionist agendas, and tariffs and threats of tariffs have been on the news (Chaffin, 2012). These trade wars increased the tension between countries, and further exacerbated the domestic-leaning consumer purchasing intentions (Balanabis \& Siamagka, 2017; Ikenberry, 2018; Mika, 2017).

In international marketing research, consumer reactions to producing countries and their firms are generally known as country of origin (COO) effects. Many researchers have examined these effects on consumer product choices, and consequently on multinational brand strategies (Magnusson \& Westjohn, 2011; Maheswaran \& Chen, 2009). The resulting general conclusion is that consumers' product judgments generally display a bias in favor of domestic products or brands over foreign alternatives (Papadapoulos, Heslop, \& Bamossy, 1990; Verlegh, 2007; Verlegh \& Steenkamp, 1999). 
Within this research, consumer ethnocentrism is a popular construct (Sharma, 2015). It is used to explain the consumers' generally favorably bias towards domestic products and brands in a number of studies (Baughn \& Yaprak, 1993; Peterson \& Jolibert, 1995). American consumers' negative attitude towards foreign brand cars, or the Japanese consumers' loyalty to Japanese products are couple of classic examples of consumer ethnocentrism. According to seminal work of Shimp and Sharma (1987), ethnocentric consumers object to buying imported goods because this behavior is viewed as harmful to national economy, and thus considered unpatriotic. In other words, the consumer ethnocentrism construct was first developed as an act of economic nationalism, and encompasses issues such as the morality of buying imported products, and prejudice against imports (Sharma, Shimp, \& Shin, 1995). However, it is unlikely that economic concerns are the sole motivator of consumer preferences for domestic products. Building on social identity theory, Verlegh (2007) shows that this home country bias is also in part driven by a need for self enhancement. Accordingly, consumers express their identity through consumption. Whatever its cause may be, ethnocentrism is identified as an important factor affecting the consumer willingness to buy domestic versus foreign products (Wang \& Chen, 2004). However, it only partly explains the consumer evaluation of foreign products.

Another relevant construct for understanding $\mathrm{COO}$ effects comes from the consumer animosity in Klein, Ettenson, and Morris (1998). Accordingly, animosity predicts willingness to purchase foreign goods over and above consumer ethnocentrism with specific foreign countries or foreign companies as targets. Funk, Arthurs, Trevino, and Joireman (2010) show that U.S. consumers' willingness to purchase a product is lower if it has been manufactured in an animosity-evoking country. Negative image of Russian products in Eastern European markets, and avoidance of American brands in some European and Middle Eastern countries can be counted as examples of consumer animosity. Subsequent studies have distinguished different causes for and evaluated the impact of such behavior across different times, source and target countries, product categories, and regions within a country (Riefler \& Diamantopoulos, 2007). Harmeling, Magnusson, and Singh (2015) provide a list of studies on animosity between specific countries. Several studies support the idea that animosity affects the purchase behavior independent of product quality judgments (Funk et al., 2010; Klein, 2002; Maher, Clark, \& Maher, 2010). Several studies also found a significant relationship between animosity and product quality judgments (Ettenson \& Klein, 2005; Harmeling et al., 2015; Leong et al., 2008). Whether that relationship exists or not, it can be safely said that consumer animosity affects consumer willingness to purchase in addition to ethnocentrism.

To measure consumer ethnocentrism, the international marketing literature generally uses CETSCALE, developed by Shimp and Sharma (1987). Ample research has attested to the value of this as a construct, highlighting its impact on purchase intentions (Good \& Huddleston, 1995; Shimp \& Sharma, 1987; Wang \& Chen, 2004). Several studies, such as Chandon, Morwitz, and Reinartz (2005), use purchase intention as a proxy measure for purchasing behavior. However, research on how consumer ethnocentrism affects actual purchase behavior is scarce (Witkowski, 1998; Yu \& Albaum, 2002). In fact, research has shown that there is substantial variation among the correlations ranging from 0.15 to 0.92 (Sheppard, Hartwick, \& Warshaw, 1988). Furthermore, while most researchers have simply assumed this measure to have same operational structure in other countries as in the United States where it is developed, Sharma (2015) finds limited evidence about CETSCALE's validity, dimensionality, and crosscultural measurement invariance.

Recent literature findings also suggest that other constructs working in opposite direction to the influences of consumer ethnocentrism and animosity. Riefler, Diamantopoulos, and Siguaw (2012) explore cosmopolitanism, which endorses a reflective distance from one's own cultural affiliation and openness towards other cultures. In contrast to ethnocentrism, this literature expects this consumer group to be particularly responsive to foreign goods (Beckmann et al., 2001; Nijssen \& Van Herk, 2005). For example, especially in developing countries, young consumers view of Western products as a symbol of status, and consequently prefer for foreign brands over local ones. This allows a potentially powerful segmentation base for companies seeking to target international consumer markets (Cannon \& Yaprak, 2002; Jaffe \& Nebenzahl, 2006). The cosmopolitan orientation of consumers also manifests itself in a conscious consumption of produces originating from cultures other than their own (Caldwell, Blackwell, \& Tulloch, 2006). The marketing literature has previously offered two cosmopolitanism scales, namely CYMYC developed by Cannon, Yoon, McGowan, and Yaprak (1994), and the more recent COS scale by Cleveland and Laroche (2007), which has been applied to crossnational research.

Similarly, drawing from negativity bias, fading affect bias, and ambivalence literatures, several researchers such as Gineikiene and Diamantopoulos (2017) provide evidence that consumer nostalgia acts as a countervailing force to consumer animosity in historically connected markets. Growing demand for Turkish cultural TV productions in Middle Eastern and South Eastern European markets is an example of this nostalgia. In historically connected markets, animosity may have adverse influence on product evaluations, which negatively influences foreign product buying behavior (Shankarmahesh, 2006; Shoham \& Gavish, 2010). In contrast, consumer nostalgia may reflect a preference, positive attitude towards objects that were more common in such markets (Gineikiene, 2013; Sedikides et al., 2015).

In this research, given the lack of clarity on whether intentions leading to actual purchases and using measures the validity of which has been questioned in the literature, I develop measures of consumer ethnocentrism versus cosmopolitanism and consumer animosity versus nostalgia based on actual consumption patterns from cross-border trade data. To do this, I turn to the border effects literature in international economics. In contributing towards answering Buckley, Doh, and Benischke's (2017) question of how multinationals can cater to rising middle class consumers in emerging economies, these measures are applied in a comparative study of 140 least developed, emerging and developed countries in early 2010s. Discussions on the results for G-20 economies, emerging economies, and implications for managers in multinational enterprises conclude the article. 


\section{2 | BORDER EFFECTS}

The border effect puzzle in international trade literature was first presented by McCallum (1995). The original finding was that Canadian provinces traded over 20 times with each other than they did with states in the Unites States of the same size and distances. In other words, consumers' actual purchases demonstrate a strong preference for domestically made products. At the time, Obstfeld and Rogoff (2000) referred to the border effect as one of the six major puzzles in international macroeconomics. Later on, this research has gone on to spawn a larger and growing literature on so-called border effects.

The international economists came up with various explanations for the border effect puzzle. One is the mismeasurement of border effects, which is addressed in Head and Mayer (2002). Another one is trade barrier related border effects. In other words, tariffs alter the relative prices in favor of domestic products; consequently shifting the consumer preferences against imported products (Rauch, 2001). The last explanation overlaps with the earlier discussions and findings from the international marketing literature: high elasticity of substitution between domestic and imported alternatives (Head \& Ries, 2001). These may stem from cultural differences or historical military or political confrontations, may lead to consumers not preferring foreign-made products, and making purchasing decisions in favor of domestic products. In this article, I follow Head and Mayer (2002) to address the mismeasurement issues, control for tariffs, and dissect the border effects along with consumer ethnocentrism versus cosmopolitanism and consumer animosity versus nostalgia dimensions. It must be noted that while the use of actual trade data addresses the issues related to lack of clarity about purchasing intentions translating into actual purchases; the measure developed here does not capture ethnocentrism or animosity faced by a foreign brand. Foreign brands may be produced domestically or alternative locations since these are not necessarily exported from countries where the brand is associated it.

International economists have estimated gravity equations to investigate the determinants of bilateral trade after controlling for the sizes of trade partners and the geographic distances separating them. These models have been quite successful in systematically integrating multiple dimensions of cross-border activity (Ricart, Enright, Ghemawat, Hart, \& Khanna, 2004). Wei (1996) showed how the gravity equation could also be used to estimate border effects by computing internal distance and domestic trade using the difference between domestic production and exports to other countries. He then added a dummy variable that takes the value of 1 for the observations of domestic trade, and interpreted its coefficient as the border effect. Anderson and van Wincoop (2003) offered an alternative approach. However, that requires custom programming to perform the constrained minimization. They also suggested that the border effects had an asymmetric effect on countries of different size and in particular a larger effect on small countries. To avoid this bias, Feenstra (2002) re-derived the gravity equation while introducing trade barriers, such as transportation costs or tariffs, following Redding and Venables (2000).

Most of the border effect literature used point-to-point measures for internal and international bilateral distances. Citing issues in treating economies as dimensionless points, Head and Mayer (2002) argued that the measured effect of national borders on trade seems too large to be explained by the apparently small border-related trade barriers. Helliwell and Verdier (2001) argued that obtaining reasonable estimates of potential domestic trading distances is an essential precondition of comparing internal and external data trade densities. To address this Head and Mayer (2002) developed a measure of distance that would be consistent for international as well as domestic trade flows. Building on their measure, Mayer and Zignago (2005) computed internal and international bilateral distances in a totally consistent way, which is important for obtaining a correct estimate of the border effects. They have developed a theoretically consistent method for identifying national border effects and computed these distances using city-level data to assess the geographic distribution inside each nation. Without a need for custom programming, their model can be estimated using ordinary least squares. Hence, this article follows that stream of research.

According to Anderson and van Wincoop (2003), the utility of the representative consumer from country $j$ is:

$$
U_{j}=\left(\sum_{i} \sum_{v=1}^{n_{j}}\left(s_{i j} c_{v i j}\right)^{\frac{\sigma-1}{\sigma}}\right)^{\frac{\sigma}{\sigma-1}},
$$

$s_{i j}$ can be thought of as the perception of consumers in $j$ of the varieties from country $i$, measured in services per unit consumed. Note that I deviate from Anderson and van Wincoop (2003), which assumes a single variety, and same perception of goods by consumers in every country. In particular, the services offered by a good delivered to $j$ are proportional to those offered in $i$ by $\gamma_{i j}$. The values of this parameter less than 1 can be interpreted as repulsion of consumers in $j$ of products from $i$ stemming from their general ethnocentrism and animosity towards i. Similarly, values larger than 1 can be interpreted as attraction of consumers in $j$ to products from $i$ resulting from their general cosmopolitanism and nostalgia for $i$ :

$$
s_{i j}=\gamma_{i j} s_{i} .
$$

Consumers in $j$ maximize its utility subject to the following budget constraint:

$$
y_{j}=\sum_{i} \sum_{v=1}^{n_{j}} p_{i j} c_{v i j} .
$$

The solution determines exports from $i$ to $j$ as follows:

$$
x_{i j}=\frac{n_{i}\left(p_{i j} / s_{i j}\right)^{1-\sigma}}{\sum_{h} n_{h}\left(p_{h j} / s_{h j}\right)^{1-\sigma}} y_{j},
$$

where exports are influenced by the perception-adjusted prices of $n$ varieties produced in $i$ by consumers in $j$ relative to alternative exporter countries $h$. 
Following the standard practice, the prices faced by consumers in $j$ are influenced by a combination of transport costs proportional to distance and most favored nation tariff rates that apply all WTO members, $t_{j}$, proportional to prices:

$$
p_{i j}=\left(1+t_{j}\right)^{B} d_{i j}{ }^{\theta} p_{i}
$$

where $B$ is zero if there is a free trade agreement between $i$ and $j$, including domestic trade, one otherwise. The approach in Head and Mayer (2002) is followed to eliminate the unobservable parameters in this exports equation, and to arrive to a regression equation that can be estimated using ordinary least squares, I define $\pi$ as the geometric mean of odds of buying domestic relative to $j$ in country $i$, and vice versa:

$$
\begin{gathered}
\pi_{i j}=\sqrt{\frac{x_{i i} x_{j j}}{x_{j i} x_{i j}}}, \\
\pi_{i j}=\sqrt{\left(\frac{d_{i j} d_{j j}}{d_{i j}{ }^{2}}\right)^{\theta(1-\sigma)} \frac{\left(\gamma_{i j} \gamma_{j i}\right)^{1-\sigma}}{\left(\left(1+t_{i}\right)\left(1+t_{j}\right)\right)^{1-\sigma}}} .
\end{gathered}
$$

$x_{i i}$ and $x_{j j}$ are domestic trade in countries $i$ and $j$ respectively. $d_{i i}$ and $d_{j j}$ are internal distances for $i$ and $j$. Note that $d_{i j}=d_{j i}$. By defining the following variables and taking logs of the above, I obtain the following regression equation:

$$
\begin{gathered}
D_{i j}=\frac{d_{i j} d_{j j}}{d_{i j}{ }^{2}}, \\
T_{i j}=\left(1+t_{i}\right)\left(1+t_{j}\right), \\
\ln \pi_{i j}=\frac{1}{2}(1-\sigma) \ln \left(\gamma_{i j} \gamma_{j i}\right)+\frac{1}{2} \theta(1-\sigma) \ln D_{i j}-\frac{1}{2}(1-\sigma) \ln T_{i j} .
\end{gathered}
$$

$D_{i j}$ is basically the factor of internal to international distance ratios for the two countries. Similarly, $T_{j j}$ is the factor of tariff rates. Unlike Head and Mayer (2002), only part of $\gamma_{i j}$ and $\gamma_{j i}$ are considered to be symmetric: Perceptions of consumers in one country about the others' products are partially due to reciprocally shared factors such as cultural distance, bilateral history, and so forth. This can be interpreted as consumer animosity versus nostalgia. Additionally, there may be deviations from this shared perception for consumers in each country. This repulsion from anything foreign can be considered as consumer ethnocentrism versus cosmopolitanism. Hence, the estimation equation includes country fixed effects and bilateral fixed effects as follows:

$$
\ln \pi_{i j}=\alpha_{i}+\alpha_{j}+\alpha_{i j}+\beta \ln D_{i j}+\tau \ln T_{i j}+\varepsilon_{i j}
$$

Using the above, consumers in $j$ 's assessment of products from $i$ can be estimated in a multiplicative form of consumer animosity versus nostalgia and ethnocentrism versus cosmopolitanism, respectively, as follows:

$$
\gamma_{i j}=e^{\left[-\frac{a_{i j}}{2 \tau}\right]} \cdot e^{\left[-\frac{a_{i}}{\tau}\right]}=\frac{\text { nostalgia }_{i j}}{\text { animosity }_{i j}} \cdot \frac{\text { cosmopolitanism }_{j}}{\text { ethnocentrism }} \text {. }
$$

\section{3 | DATA AND METHODOLOGY}

Cross-sectional analysis is carried out to measure the degree of consumer ethnocentrism versus cosmopolitanism in each country, and the degree of bilateral animosity versus nostalgia between pairs of countries. Equation (11) is estimated using ordinary least squares using data for five different sectors. Country and bilateral fixed effects in this equation are gradually added towards the full model under Models (1), (2), and (3) as follows:

$$
\begin{gathered}
\text { Model (1): } \ln \pi_{i j}=\alpha+\beta \ln D_{i j}+\tau \ln T_{i j}+\varepsilon_{i j} . \\
\text { Model (2): } \ln \pi_{i j}=\alpha+\alpha_{i}+\alpha_{j}+\beta \ln D_{i j}+\tau \ln T_{i j}+\varepsilon_{i j} . \\
\text { Model (3) }: \ln \pi_{i j}=\alpha_{i}+\alpha_{j}+\alpha_{i j}+\beta \ln D_{i j}+\tau \ln T_{i j}+\varepsilon_{i j} .
\end{gathered}
$$

Availability of domestic trade and tariffs in the classification needed is the primary reason for the time period selected. All countries of the world are included in the analysis as long as data is available. Time period analyzed is 2010-2014, which maximizes the number of data points. Rather than annual data, cumulative data over the years for each sector between country pairs constitute a single data point. This approach reduces the impact of annual fluctuations in trade. Overall, the data included 139 countries, and 20,568 dyadic data points between country pairs.

The results are presented for G20 countries as well as emerging markets. Not every institution agrees on the list of emerging markets. Please see Table 1 for the list from various institutions. The International Monetary Fund and Morgan Stanley Capital International classify 23 countries as emerging markets, with some differences. Standard \& Poor's, and Dow Jones each classify 21 countries as such, while Russell lists 18 countries. The following countries are identified as emerging markets across all institutions: Brazil, Chile, China, Colombia, Hungary, India, Indonesia, Malaysia, Mexico, Peru, Philippines, Russia, South Africa, Thailand, and Turkey. In this article, I include all emerging markets listed by any of these institutions. Taiwan, while included in some of the lists, is not analyzed in this study due to lack of data. In the analysis, a comparison of results is also made between emerging versus developed economies. The UN definition of developed country is adopted, which includes 30 countries. Some of the emerging countries also listed as developed by UN, such as Hungary and Poland, are kept in the emerging country list.

Definition of the variables used in the analysis is summarized in Table 2, and are explained below.

\section{1 | Trade data}

Following Wei (1996), the difference between domestic production and exports is used for domestic trade. Data on domestic production 
TABLE 1 G20 and emerging markets (EM)

\begin{tabular}{|c|c|c|c|c|c|c|}
\hline Countries & G20 & IMF & $\mathrm{MSCl}$ & $S \& P$ & Russell & Dow Jones \\
\hline Argentina & $\mathrm{G} 20$ & EM & & & & \\
\hline Australia & G20 & & & & & \\
\hline Bangladesh & & EM & & & & \\
\hline Bulgaria & & EM & & & & \\
\hline Brazil & G20 & EM & EM & EM & EM & EM \\
\hline Canada & G20 & & & & & \\
\hline Chile & & EM & EM & EM & EM & EM \\
\hline China & G20 & EM & EM & EM & EM & EM \\
\hline Colombia & & EM & EM & EM & EM & EM \\
\hline Czechia & & EM & EM & EM & EM & \\
\hline Egypt & & & EM & EM & & EM \\
\hline France & G20 & & & & & \\
\hline Germany & $\mathrm{G} 20$ & & & & & \\
\hline Greece & & & EM & EM & EM & EM \\
\hline Hungary & & EM & EM & EM & EM & EM \\
\hline India & G20 & EM & EM & EM & EM & EM \\
\hline Indonesia & G20 & EM & EM & EM & EM & EM \\
\hline Italy & G2O & & & & & \\
\hline Japan & G20 & & & & & \\
\hline Malaysia & & EM & EM & EM & EM & EM \\
\hline Mexico & G20 & EM & EM & EM & EM & EM \\
\hline Pakistan & & EM & EM & EM & & \\
\hline Peru & & EM & EM & EM & EM & EM \\
\hline Philippines & & EM & EM & EM & EM & EM \\
\hline Poland & & EM & EM & EM & EM & \\
\hline Qatar & & & EM & EM & & EM \\
\hline Romania & & EM & & & & \\
\hline Russia & $\mathrm{G} 20$ & EM & EM & EM & EM & EM \\
\hline Saudi Arabia & G20 & & & & & \\
\hline South Africa & G20 & EM & EM & EM & EM & EM \\
\hline South Korea & G20 & & EM & & & \\
\hline Thailand & EM & EM & EM & EM & EM & \\
\hline Turkey & G20 & EM & EM & EM & EM & EM \\
\hline Ukraine & & EM & & & & \\
\hline UAE & & & EM & EM & EM & EM \\
\hline United Kingdom & G20 & & & & & \\
\hline United States & G20 & & & & & \\
\hline Venezuela & & EM & & & & \\
\hline
\end{tabular}

is only available under ISIC revision 3 classification at sector level through United Nations Industrial Development Organization's International Yearbook of Industrial Statistics. This data includes five sectors: chemicals (division 24); textiles and clothing (divisions 17-19); machinery and transport equipment (divisions 29, 30, 32, 34, and 35); food, beverage, and tobacco (divisions 15-16); and other manufacturing sectors (covering wood, paper, petroleum, metals and minerals, and other industries; divisions 20-23, 25-28, 31, 33, and 36). Corresponding bilateral trade data on these sectors are obtained from the World Bank using its WITS tool. These values for domestic and bilateral trade data are used to compute, that $\pi_{i j}$ using Equation (6) for each sector separately.

\section{2 | Distance data}

Internal and international distances are obtained from CEPII which follows the approach in Mayer and Zignago (2005). Specifically, distw 
TABLE 2 Variable definitions and sources

\begin{tabular}{|c|c|c|}
\hline Variables & Source & Definition \\
\hline$\pi_{i j}$ & $\begin{array}{l}\text { World Bank WITS \& } \\
\text { UN Industrial } \\
\text { Development Org. } \\
\text { Yearbook of } \\
\text { Industrial Statistics }\end{array}$ & $\begin{array}{l}\text { Geometric mean of odds of } \\
\text { buying domestic: Square } \\
\text { root of factor of domestic to } \\
\text { international trade with } \\
\text { partner ratios for both } \\
\text { countries per Equation (6) }\end{array}$ \\
\hline$\alpha_{i}, \alpha_{j}$ & $N / A$ & $\begin{array}{l}\text { Country fixed effects: } 1 \text { for a } \\
\text { country with any trade } \\
\text { partner }\end{array}$ \\
\hline$\alpha_{i j}$ & $\mathrm{~N} / \mathrm{A}$ & $\begin{array}{l}\text { Bilateral fixed effects: } 1 \text { for } \\
\text { trade between two specific } \\
\text { trade partners }\end{array}$ \\
\hline$D_{i j}$ & $\begin{array}{l}\text { CEPII Mayer and } \\
\text { Zignago (2005) }\end{array}$ & $\begin{array}{l}\text { Factor of internal to } \\
\text { international distance ratios: } \\
\text { Factor of domestic to } \\
\text { international distance with } \\
\text { partner ratios for both } \\
\text { countries per Equation (8) }\end{array}$ \\
\hline$T_{i j}$ & UNCTAD TRAINS & $\begin{array}{l}\text { Factor of tariff rates: Factor of } \\
\text { tariff rates plus } 1 \text { per } \\
\text { Equation (9) }\end{array}$ \\
\hline
\end{tabular}

variable from their Geodist database is used. This variable uses weighted city level data, and incorporates cities' geographic distribution to measure both international bilateral and internal domestic distances. Following Equation (8), these distances are used to compute $D_{i j}$, the factor of internal to international distance ratios for each trade partner.

\section{3 | Tariff data}

The main restriction on country coverage in the analysis is the availability of tariff data. These are obtained from UNCTAD's TRAINS database. Effectively applied tariff rates (AHS) are used, which are most favored nation applied tariffs in absence of a free trade agreement, or preferential tariffs under such agreements. These are average tariff rates weighted according to trade values for each ISIC Revision 3 Divisions to obtain sector tariff rates. Tariff rates for domestic trade are assumed to be $0 \%$. Following Equation (9), these tariff rates are used to compute $T_{i j}$, the factor of tariff rates for each trade partner.

\section{4 | RESULTS AND MANAGERIAL IMPLICATIONS}

Results of the regression equation (11) can be found in Table 3. The models gradually introduce country fixed effects, and bilateral fixed effects to the regression equation. These initial results confirm the face validity of the data used and the analysis. In all models, the independent variables are statistically significant and have the expected signs suggested by the mainstream international trade theory and obtained empirical analyses of gravity models: the odds of buying domestic between trade partners is negatively related to the ratio of internal to international distance, and positively related to tariff rates. In other words, a country is more likely to buy domestic relative to importing from another country, when the distance in between is larger. This is primarily because of larger transportation costs of goods between two countries that are far from each other. Additionally, high tariff barriers between countries make domestic consumption more likely than consuming imported products, as tariffs increase the price of imported goods relative to domestic alternatives. It is noteworthy that as fixed effects are introduced the explanatory power of the model increases substantially while the independent variables maintain their sign and significance.

In the final model (3), the independent variables and fixed effects explain over $97 \%$ of the variation in the dependent variable. These effects are used to measure degrees of consumer ethnocentrism versus cosmopolitanism in a country, and degree of consumer animosity versus nostalgia between a country pair.

The punchline of the results detailed below is that despite growing ethnocentric tendencies among consumers, these purchasing intentions against imports do not necessarily translate into actual consumption behavior in cross-border trade. It is quite possible that the consumers lack information on $\mathrm{COO}$ of production, and their actual purchasing decisions are based on perceived origin of product brands.

\subsection{Ethnocentrism versus cosmopolitanism}

Figure 1 shows country fixed effects, $\alpha_{j}$, used to compute the degree to ethnocentrism versus cosmopolitanism in each country. Overwhelming majority of the countries, 119 , are cosmopolitan. In only 20 countries in the analysis, there is preference for domestic products. Specifically, several Central American states such as Honduras, Nicaragua, El Salvador and Guatemala, along with some Southeast Asian countries such as Indonesia, Vietnam, Myanmar, and the Philippines have the highest degree of ethnocentrism in the world. Additionally, Ukraine in Europe, Tanzania in Africa, China and India in Asia are most ethnocentric countries of their region. These results support Dube and Black's (2010) finding that ethnocentrism levels increase following traumatic events. Natural disasters such as Hurricane Mitch, Juan, and Felix devastated the Central American states, in addition to violence between fighting factions such as U.S. supported contras guerillas versus Sandinista government in Nicaragua probably played a role in turning these countries more ethnocentric and focused on their domestic production. Occupation by multiples of major powers may have also triggered more nationalist consumption behavior such as in India by United Kingdom, the war between United States versus China supported Vietnam, United States and the Japanese occupation of the Philippines in post war period, and more recently traumatic events prior to Russia's annexation of half of Ukraine to name a few.

On the other end of the scale, very small countries tend to be the most cosmopolitan, such as Barbados, Costa Rica, Bahrain, Brunei, Luxembourg, and Malta. Among the larger economies, Argentina, the 
TAB LE 3 Determinants of geometric mean of odds of buying domestic between trade partners, $\pi_{j j}$

\begin{tabular}{|c|c|c|c|c|}
\hline Variables & \multicolumn{4}{|c|}{ Expected } \\
\hline \multirow[t]{2}{*}{ Constant } & & 3.11 & 4.53 & \multirow[t]{2}{*}{ N.A. } \\
\hline & & $(0.00)$ & $(0.00)$ & \\
\hline Country fixed effects & & N.A. & Not listed & Not listed \\
\hline Bilateral fixed effects & & N.A. & N.A. & Not listed \\
\hline \multirow{2}{*}{$\begin{array}{l}D_{i j} \text {, factor of internal to international distance ratios for } \\
\text { trade partners }\end{array}$} & \multirow[t]{2}{*}{-} & -0.63 & -0.88 & -3.74 \\
\hline & & $(0.00)$ & $(0.00)$ & $(0.01)$ \\
\hline \multirow[t]{2}{*}{$T_{i j}$, factor of tariff rates } & \multirow[t]{2}{*}{+} & 5.76 & 2.67 & 2.21 \\
\hline & & $(0.00)$ & $(0.00)$ & $(0.00)$ \\
\hline
\end{tabular}

Note: Numbers in parentheses are two-tailed $p$ values.

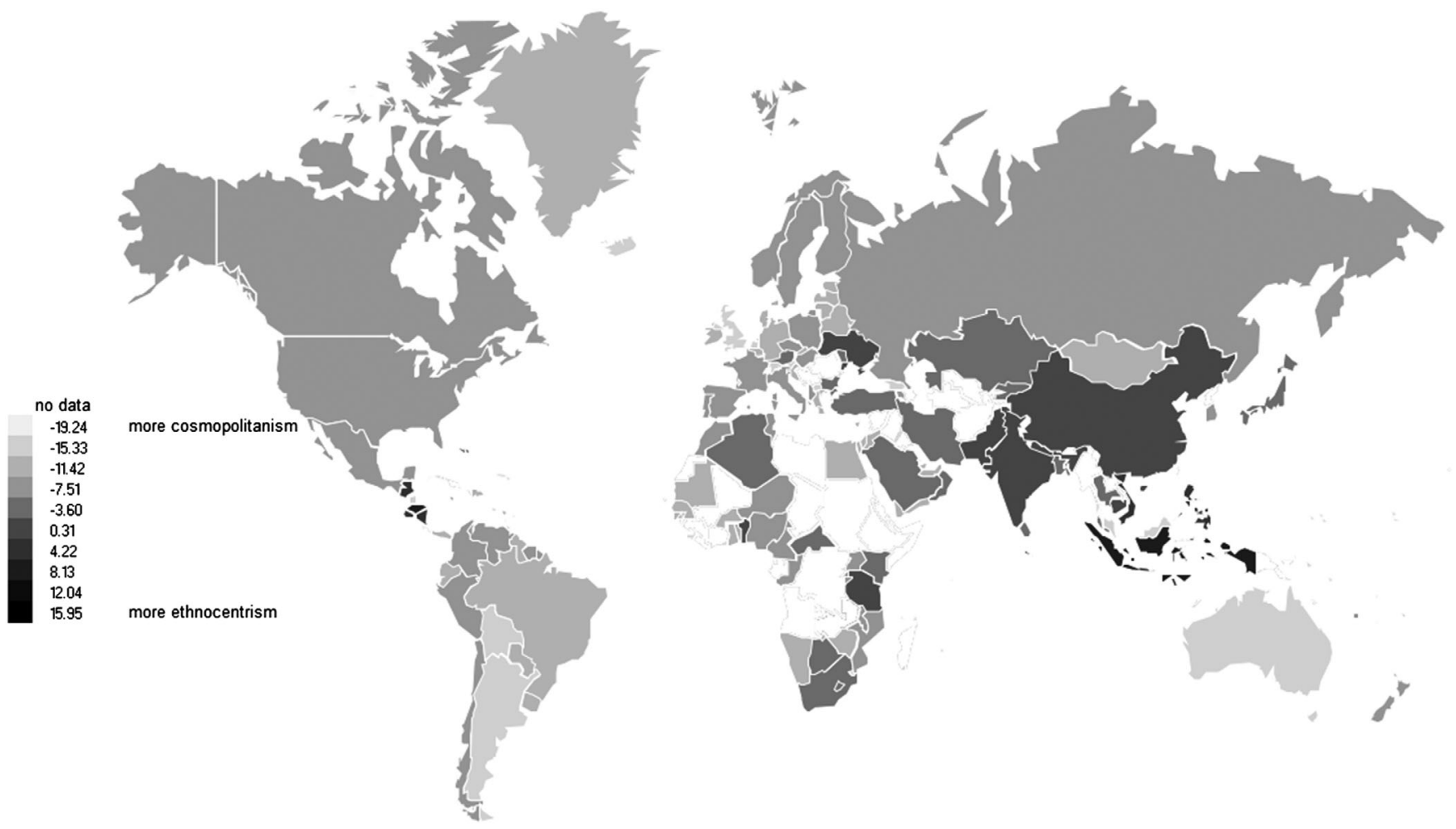

FIGURE 1 Consumer ethnocentrism versus cosmopolitanism in the world

Netherlands, and the United Kingdom have the largest cosmopolitan consumers. The number of European countries in the list is striking: 12 of the top 25 cosmopolitan countries are in Europe. Furthermore, there is no ethnocentric developed country. Decades of economic integration efforts, richer and more educated middle classes in Europe may have contributed to this result in Europe. This result in smaller countries also makes common sense. These countries typically do not have the capacity to produce in every small or large sector of an economy, so they have been used to buying foreign and not necessarily view that against their national interests.

One surprising result is the situation of emerging countries. This study finds 7 ethnocentric emerging countries out of 31 analyzed in comparison to 20 ethnocentric countries out of 139 overall. This result is in contrast to some findings in the literature that consumers in emerging markets are less ethnocentric (Hamin, 2006; Nguyen, Nguyen, \& Barrett, 2008). These emerging countries are China, 
Indonesia, Thailand, the Philippines, India, Pakistan, and Ukraine. Note that these are sizeable countries in terms of their economies, and have not participated in free trade agreements as much early on. Three of them are in G20, and Thailand, the Philippines are in top 30 and 40 largest economies of the world. This implies that they have large and diversified domestic sectors. This coupled with lack of exposure to foreign products due to few free trade agreements at time of this study may explain their preference for domestic brands.

\subsection{Animosity versus nostalgia}

The simple average of bilateral fixed effects, $\alpha_{i j}$, for each country $j$ is plotted in Figure 2. These capture the degree of animosity versus nostalgia between pairs of countries. Note that these are assumed symmetric in the analysis. In other words, $\alpha_{i j}$ and $\alpha_{j i}$ are equal. Figure 3 plots the weighted averages, where the weights are the imports of $j$ from $i$. Clearly, whether there is an overall animosity or nostalgia between two countries is impacted by the size of the weights, and simple average ignores the relative importance of some markets.

Some ethnocentric Central American states are also among the highest in terms of nostalgia towards other countries: Honduras, Nicaragua, El Salvador, and Guatemala. This is also the case for the ethnocentric Southeast Asian countries of the Philippines, Indonesia, Cambodia, and Vietnam. Other small island countries are also very nostalgic towards other countries: Singapore, Sri Lanka, Fiji, and Mauritius. Their colonization by major powers may have a role in this nostalgia. In addition to occupation of the Central American and Southeast Asian countries discussed earlier, these small island countries were colonized and relatively recently obtained their independence: Singapore in 1965, Sri Lanka in 1948 and Fiji in 1970, and Mauritius in 1965, all from United Kingdom. As a result of decades of rule under United Kingdom, there may be some nostalgia in being part of a larger imperial state, and consequently favorable actual purchases of products from their former colonizer. Among larger economies, China, India, South Africa, and Japan highly in terms of nostalgia. Smaller European countries have the highest animosity towards other countries: Luxembourg, Latvia, Lithuania, Croatia, and Slovenia. While their situation may appear similar to that nostalgic island countries considered earlier, an important difference is that these countries have been violent battlegrounds between major powers particularly during World War II. This is in contrast to rather than stable long-term colonization small island countries considered earlier. Additionally, they have generally been part of federal state structures (except Luxembourg), such as the former Soviet Union and the former Yugoslavia, where they struggled for their own unique identity. Among larger economies, Netherlands, United Kingdom, Argentina, Germany, and France have the highest animosity in weighted terms.

Weighing the animosity versus nostalgia measures with partner countries increases animosity in 98 of 130 countries. The largest increases in animosity occur in Lesotho, and smaller European countries of Luxembourg, Belgium, Austria, Latvia, and Ireland. In contrast, the biggest increases in nostalgia are observed in the following countries: Panama, and several African countries such as Niger, Nigeria,

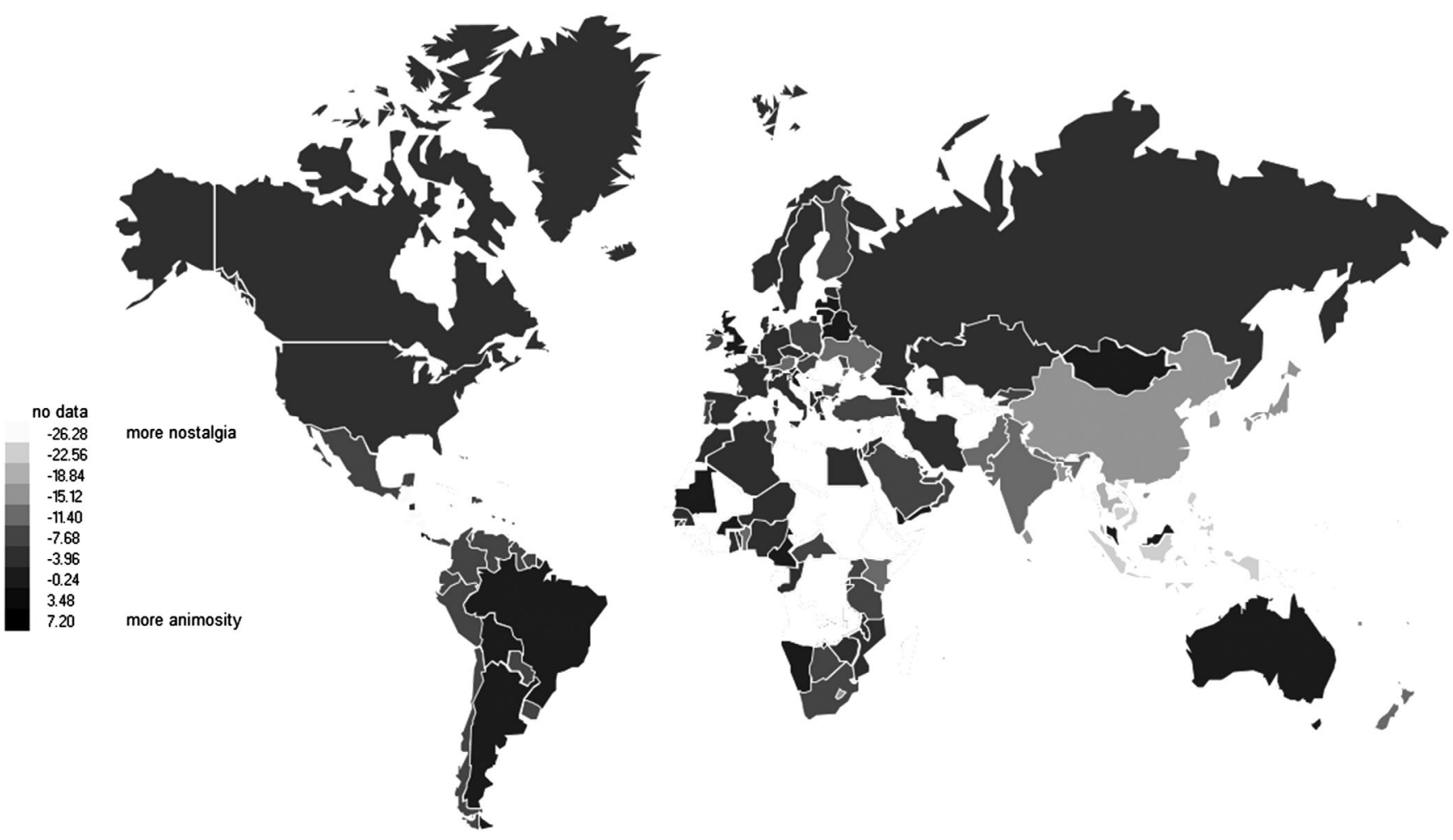

FIGURE 2 Simple average consumer animosity versus nostalgia in the world 


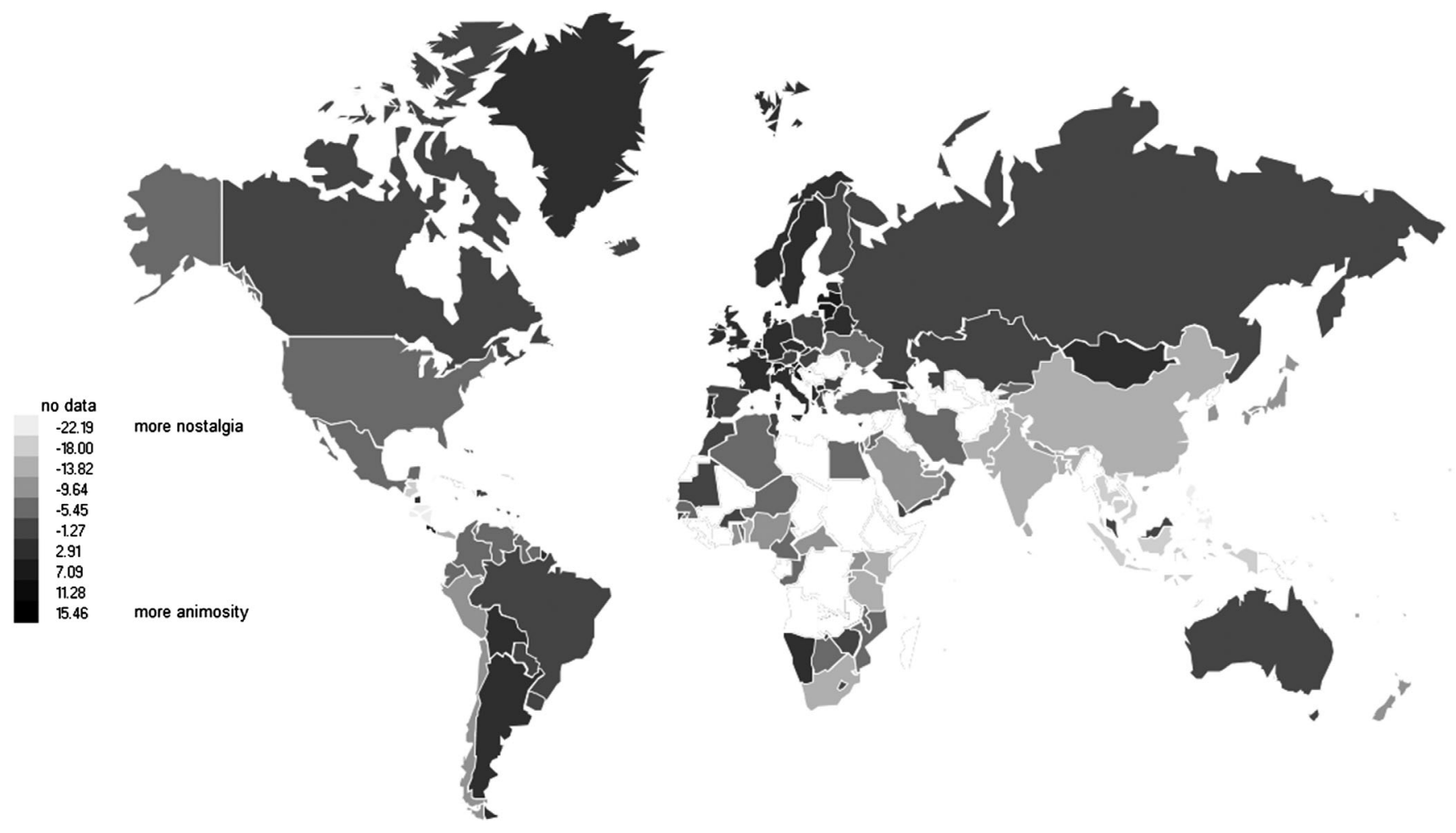

FIGURE 3 Weighted average consumer animosity versus nostalgia in the world

Kenya, Uganda, Tanzania, Ghana, and South Africa. Overall, of 15,159 country pairs, 10,887 are nostalgic towards each other, and generally open to buying imports from their trade partners.

\subsection{Emerging and G20 countries}

Table 4 presents the results for emerging and G20 countries for easy comparison. These results are particularly important to see if intentions translate into actual purchasing behavior. In the literature, it was shown that consumers generally perceive products made in developed countries to be of higher quality compared with products made in emerging countries (Josiassen \& Harzing, 2008; Pappu, Quester, \& Cooksey, 2007; Usunier \& Cestre, 2008). Specifically, consumers in emerging markets perceive imported products from other emerging markets either of similar or inferior quality (Hu, Li, Xie, \& Zhou, 2008; Kinra, 2006; Wang \& Yang, 2008). Additionally, consumers in developed markets perceive products from other developed to be of similar or superior quality to domestic (Gurhan-Canli \& Maheswaran, 2000). While whether the perceptions of quality translate into actual buying may depend on affordability/income level in the importer country, the results of the measure in this article show the following: out of country pairs where one of the partners is developed, in $63 \%$, there is attraction towards the imported product. In 810 cases, where both partners are developed, only $38 \%$ of the pairs demonstrate attraction. These ratios are $77 \%$ when one of the partners is emerging and $82 \%$ when both are emerging. These results indicate that a developed country has more animosity towards another country, particularly another developed country, while an emerging country is open to imports from another country, particularly another emerging country. This may be a particular result may be associated with the time period analyzed. In early 2010s, emerging economies were benefiting from globalization and had positive views towards it, while the opposite was an emerging trend in developed countries due to various economic and financial crises they were dealing with.

Table 4 also lists the attraction versus repulsion parameter $\gamma_{i j}$, for large economies of G20 and for emerging countries, $j$, resulting from ethnocentrism versus cosmopolitanism and from animosity versus nostalgia weighted averaged over trade partners, $i$, and list of several significant partners with high animosity. Equation (12) is used to obtain these parameters using the country and bilateral fixed effects and the coefficient of the tariff variable in the regression model (3). Overall attraction versus repulsion is computed by multiplying the two. The countries in this table are sorted in increasing attraction to imports from other countries. The list of country pairs with prominent animosities is mostly as expected from their shared history. These include Saudi Arabia versus Iran, Saudi Arabia versus Yemen, Egypt versus Israel, Greece versus Macedonia, Greece versus Albania, Turkey versus Greece, France versus United Kingdom, United Kingdom versus Germany, Russia versus United Kingdom, Poland versus Germany, and so forth. It is noteworthy that countries generally tend to have animosity towards imports from neighboring countries. In terms of attraction versus repulsion parameter, half of 36 countries presented in the table have an attraction to imported 
TAB LE 4 Ethnocentrism versus Cosmopolitanism and Nostalgia versus Animosity in G20 and emerging markets

\begin{tabular}{|c|c|c|c|c|}
\hline Country & $\begin{array}{l}\text { Ethno. }(<1) \\
\text { Cosmo. }(>1)\end{array}$ & $\begin{array}{l}\text { Weighted } \\
\text { Animosity }(<1) \\
\text { Nostalgia }(>1)\end{array}$ & $\begin{array}{l}\text { Overall } \\
\text { Repulsion (<1) } \\
\text { Attraction (>1) }\end{array}$ & $\begin{array}{l}\text { \#countries } \\
\text { w/ animosity }\end{array}$ \\
\hline Indonesia (G20) & 0.02 & 53.56 & 1.15 & 1 (MYS) \\
\hline Ukraine & 0.77 & 2.524 & 1.94 & 13 (LTU, GEO, BLR, LAT, EST) \\
\hline China (G20) & 0.27 & 11.03 & 2.95 & 1 (MNG) \\
\hline Philippines & 0.05 & 69.04 & 3.48 & 0 \\
\hline India (G20) & 0.44 & 10.89 & 4.82 & 2 (MNG, MYS) \\
\hline Russia (G20) & 6.26 & 0.927 & 5.80 & 76 (GEO, LTU, EST, LVA, GBR) \\
\hline Pakistan & 0.71 & 8.869 & 6.27 & 4 (MNG, GEO, KAZ, KGZ) \\
\hline Poland & 9.05 & 0.725 & 6.56 & 34 (LTU, SVK, CZE, LVA, DEU) \\
\hline Saudi Arabia (G20) & 1.59 & 6.271 & 9.99 & 15 (GEO, YEM, BHR, IRN, EGP) \\
\hline Czechia & 23.3 & 0.443 & 10.30 & 43 (SVN, DEU, SVK, CHE, HRV) \\
\hline Hungary & 20.3 & 0.636 & 12.93 & 42 (SVK, HRV, SVN, MKD, CZE) \\
\hline Mexico (G20) & 11.1 & 1.441 & 16.04 & 19 (CRI, USA, ARG, BOL, PAN) \\
\hline Japan (G20) & 2.17 & 8.413 & 18.21 & 2 (MNG, KOR) \\
\hline Germany (G20) & 54.3 & 0.351 & 19.09 & 62 (NLD, CHE, GBR, DNK, CZE) \\
\hline Bangladesh & 1.35 & 15.13 & 20.41 & 2 (MNG, MYS) \\
\hline United States (G20) & 9.3 & 2.204 & 20.50 & 36 (CRI, CAN, ARG, MEX, BRA) \\
\hline Thailand & 0.9 & 26.62 & 23.86 & 1 (MYS) \\
\hline United Kingdom (G20) & 231 & 0.243 & 56.20 & 72 (NLD, CHE, FRA, DEU, IRL) \\
\hline Egypt & 30.1 & 2.076 & 62.55 & 44 (ISR, GEO, JOR, CYP, GRC) \\
\hline S. Korea (G20) & 14 & 4.615 & 64.57 & 3 (MNG, MYS, JPN) \\
\hline Brazil (G20) & 74.5 & 1.603 & 79.20 & 74 (ARG, BOL, BRB, CRI, PRY) \\
\hline Malaysia & 232 & 0.604 & 139.8 & 47 (MNG, AUS, SGP, KAZ, RUS) \\
\hline Argentina (G20) & 741 & 0.287 & 212.7 & 83 (URY, BOL, BRA, PRY, CHL) \\
\hline Australia (G20) & 236 & 1.084 & 255.9 & 77 (BRN, MYS, ARG, BOL, BRA) \\
\hline UAE & 53.1 & 6.736 & 357.5 & 12 (BHR, OMN, QAT, YEM, IRN) \\
\hline Qatar & 70.4 & 5.129 & 361.0 & 10 (BHR, ARE, YEM, IRN, KWT) \\
\hline
\end{tabular}

Note: Codes in parentheses are ISO Alpha-3 codes for prominent countries with highest bilateral animosity.

goods resulting from both cosmopolitanism and nostalgia. For others, while cosmopolitanism leads to attraction, the animosity leads to repulsion, or ethnocentrism leads to repulsion and the nostalgia leads to attraction. It is noteworthy that for all countries in this table, overall there is an attraction to imported products. However, there is great variation in terms of the degree of attraction. The developed G20 countries tend to be in the middle range from 8.65 (France) to 20.5
(United States) in terms of the overall attraction to imported products. Only two developed G20 countries have significantly larger attraction: Australia (255.9) and United Kingdom (56.2). Large, that is, G20 member, emerging countries tend to have less attraction with Indonesia (1.145), China (2.952), India (4.823), and Russia (5.799) with the lowest overall attraction. Smaller emerging economies in Europe tend to be in the same range as developed G20 countries, with Ukraine 
(1.936) and Bulgaria (4.348) trailing behind, and Greece (33.55) with the highest. It is noteworthy that Latin American and smaller Middle Eastern countries tend to have larger overall attraction to imported products than other countries in this table.

With increasing globalization, an important challenge for multinational companies is to identify appropriate customer segments, and target these segments in different countries (Steenkamp, Ter Hofstede, \& Wedel, 1999). In doing so, marketing professionals need to have a better understanding of foreign consumer reactions toward their brands (Leong et al., 2008). Overall, the measure proposed in this article produce results that are consistent with Usunier (2006) and Liefeld (2004). Particularly in emerging countries, COO effects are not much relevant, and individuals are open to buying imported products from other countries or do not inquire the $\mathrm{COO}$ information. This may be a result of this information becoming increasingly difficult to ascertain for consumers, due to global sourcing as suggested in Van Pham (2006).

Brand strategies involve choices between using a global brand across markets and developing brands for specific markets (Klein, 2002). Steenkamp, Batra, and Alden (2003) find that perceived brand globalness influences the likelihood of brand purchase and that many MNEs today are altering their brand portfolios in favor of global brands. The results of this article support this global brand strategy, with products that do not facilitate the switching of patriotism/ nationalism into ethnocentrism by avoiding national symbols and deemphasizing their product's national identity.

\section{5 | CONTRIBUTION TO THE LITERATURE}

$\mathrm{COO}$ is one of the most widely researched topics in international marketing (Pharr, 2005). COO does affect purchasing behavior (Demirbag, Sahadev, \& Mellahi, 2010; Phau \& Chao, 2008; Sharma, 2011), since it is often used by consumers as cue in product evaluation that would predict the consumers' behavior. Within this topic, the literature has demonstrated that consumer ethnocentrism and animosity are independent concepts affecting purchasing decisions (Klein, 2002). In particular, animosity is comprised of negative consumer feelings toward a specific country, whereas ethnocentrism concerns attitudes against buying goods from all countries. The literature also developed constructs that work in opposite directions such as cosmopolitanism starting with Cannon et al. (1994) as openness to imported products from other countries, and nostalgia where consumers exhibit positive feelings towards a specific country in their purchasing decisions starting with Holbrook and Schindler (1991). Apart from other criticisms raised in the literature, the measurement of these constructs mostly relied on surveys of individuals purchasing intentions. This limits their ability to decipher information on how intentions relate to actual purchases, and their applicability to various countries since the studies were carried out only on a handful set of countries. Hence, multinational companies are still left in the dark in terms of information on degree of consumer ethnocentrism or cosmopolitanism in many markets they are interested, and animosity or nostalgia from many markets towards the country they originate from. This study attempted to fill this gap, by developing a novel measure that reveals these using actual cross-border trade data from many countries rather than intentions, as long as this data is available. While doing this, this article drew from approaches in international economics, linking the disciplines together.

While this proposed measure relies on actual trade between countries, one drawback is that it would not capture the ethnocentrism and/or animosity towards brands associated with a country, which may not be the same as the country where it is actually produced. Jaffe and Nebenzahl (2006) correctly identify that such feelings associated with a product or brand may have nothing to do the actual country of production. In addition, the measure in this study did not take into account nontariff trade barriers into account. Future research can improve the results presented here with data on these types of trade barriers.

Since the results are available for many countries, the proposed measure makes comprehensive studies covering multiples of countries possible, informing multinational businesses better for the challenges their brands will be facing in specific markets, and provides more data points for academic research into on the roots of ethnocentrism, cosmopolitanism, nostalgia and animosity. Among other causes, Campbell (2003) suggests xenophobia for consideration. Accordingly, xenophobic people view foreign products as threats to their culture, ethnicity, religion and identity as well as rivalry against limited economic resources in a country (Campbell, 2003). Ouellet (2005) coined the term "consumer racism" to describe when consumer purchasing decisions and behaviors are driven primarily by ethnic, national and cultural origin associated with products. When choosing among foreign products, the consumers manifest favorable attitudes toward those from those countries with a similar culture (Lantz \& Loeb, 1996; Sharma et al., 1995; Watson \& Wright, 2000). With a more comprehensive data set that includes measures from many countries that are different on these dimensions, the measure developed in this article can contribute to the research on the causes of COO.

\section{ORCID}

Yener Kandogan (D) https://orcid.org/0000-0003-0827-1705

\section{REFERENCES}

Alden, D. L., Steenkamp, J. B., \& Batra, R. (2006). Consumer attitudes toward marketplace globalization: Structure, antecedents and consequences. International Journal of Research in Marketing, 23(3), 227-239.

Anderson, J. E., \& van Wincoop, E. (2003). Gravity with gravitas: A solution to the border puzzle. American Economic Review, 93(1), 170-192.

Balanabis, G., Diamantopoulos, A., Mueller, R. D., \& Melewar, T. C. (2001). The impact of nationalism, patriotism and internationalism on consumer ethnocentric tendencies. Journal of International Business Studies, 32(1), 157-175.

Balanabis, G., \& Siamagka, N. T. (2017). Inconsistencies in the behavioral effects of consumer ethnocentrism: The role of brand, product category, and country of origin. International Marketing Review, 34(2), 166-182. 
Baughn, C. C., \& Yaprak, A. (1993). Mapping country-of-origin research: Recent developments and emerging avenues. In N. Papadopoulos \& L. A. Heslop (Eds.), Product-country images: Impact and role of international marketing (pp. 89-116). New York, NY: International Business Press.

Beckmann, S., Douglas, S., Botschen, G., Botschen, M., Friese, S., \& Nijssen, E. (2001). The world minded consumer: An emic exploration. In M. C. Gilly \& J. Meyers-Levy (Eds.), Advances in consumer research (Vol. 28, pp. 138-144). Salt Lake City, UT: Association for Consumer Research.

Buckley, P., Doh, J., \& Benischke, M. (2017). Towards a renaissance in international business research? Big questions, grand challenges, and the future of IB scholarship. Journal of International Business Studies, 48(9), 1045-1064.

Caldwell, M., Blackwell, K., \& Tulloch, K. (2006). Cosmopolitanism as a consumer orientation: Replicating and extending prior research. Qualitative Market Research, 9(2), 126-139.

Campbell, E. K. (2003). Attitudes of Botswana citizens toward immigrants: Signs of xenophobia? International Migration, 41(4), 72-111.

Cannon, H., \& Yaprak, A. (2002). Will the real-world citizen please stand up! The many faces of cosmopolitan consumer behavior. Journal of International Marketing, 10(4), 30-52.

Cannon, H., Yoon, S. J., McGowan, L., \& Yaprak, A. (1994). In search of the global consumer. Paper included in Proceedings for the 1994 Annual Meeting of the Academy of International Business.

Carvalho, S. W., Luna, D., \& Goldsmith, E. (2019). The role of national identity in consumption: An integrative framework. Journal of Business Research, 103, 310-318.

Chaffin, J. (2012). Large rise in protectionist measures. Financial Times, November 2, 2015.

Chandon, P., Morwitz, V. G., \& Reinartz, W. J. (2005). Do intentions really predict behavior? Self-generated validity effects in survey research. Journal of Marketing, 69(2), 1-14.

Cleveland, M., \& Laroche, M. (2007). Acculturation to the global consumer culture: Scale development and research paradigm. Journal of Business Research, 60(3), 249-259.

Demirbag, M., Sahadev, S., \& Mellahi, K. (2010). Country image and consumer preference for emerging economic products: The moderating role of consumer materialism. International Marketing Review, 27(2), 141-163.

Diamantopoulos, A., Florack, A., Halkias, G., \& Palcu, J. (2017). Explicit versus implicit country stereotypes as predictors of product preferences: Insights from the stereotype content model. Journal of International Business Studies, 48(8), 1023-1036.

Dube, L. F., \& Black, G. S. (2010). Impact of national traumatic events on consumer purchasing. International Journal of Consumer Studies, 34(3), 333-338.

Ettenson, R., \& Klein, J. G. (2005). The fallout from French nuclear testing in the South Pacific: A longitudinal study of consumer boycotts. International Marketing Review, 22(2), 199-224.

Feenstra, R. C. (2002). Border effects and the gravity equation: Consistent methods for estimation. Scottish Journal of Political Economy, 49(5), 491-506.

Funk, C. A., Arthurs, J. D., Trevino, L. J., \& Joireman, J. (2010). Consumer animosity in the global value chain: The effect of international production shifts on willingness to purchase hybrid products. Journal of International Business Studies, 41(4), 639-651.

Gineikiene, J. (2013). Consumer nostalgia literature review and an alternative measurement perspective. Organizations and Markets in Emerging Economies, 4(2), 112-149.

Gineikiene, J., \& Diamantopoulos, A. (2017). I hate where it comes from but I still buy it: Countervailing influences of animosity and nostalgia. Journal of International Business Studies, 48(8), 992-1008.

Good, L. K., \& Huddleston, P. T. (1995). Ethnocentrism of Polish and Russian consumers: Are feelings and intentions related. International Marketing Review, 12(5), 35-48.
Gurhan-Canli, Z., \& Maheswaran, D. (2000). Cultural variations in country of origin effects. Journal of Marketing Research, 37(3), 309-317.

Hamin, G. E. (2006). A less-developed country perspective of consumer ethnocentrism and "country of origin" effects: Indonesian evidence. Asia Pacific Journal of Marketing and Logistics, 18(2), 79-92.

Harmeling, C. M., Magnusson, P., \& Singh, N. (2015). Beyond anger: A deeper look at consumer animosity. Journal of International Business Studies, 46(6), 676-693.

Head, K., \& Mayer, T. (2002). Illusory border effects: Distance measurement inflates estimates of home bias in trade (CEPII Working Paper 2002-01).

Head, K., \& Ries, J. (2001). Increasing returns versus national product differentiation as an explanation for the pattern of US-Canada trade. American Economic Review, 91(4), 858-876.

Helliwell, J., \& Verdier, G. (2001). Measuring internal trade distances: A new method applied to estimate provincial border effects in Canada. Canadian Journal of Economic, 34(4), 1024-1041.

Holbrook, M. B., \& Schindler, R. M. (1991). Echoes of the dear departed past: Some work in progress on nostalgia. In R. H. Holman \& M. R. Solomon (Eds.), Advances in consumer research (Vol. 18, pp. 330-333). Provo, UT: Association for Consumer Research.

$\mathrm{Hu}, \mathrm{X} ., \mathrm{Li}, \mathrm{L}$., Xie, C., \& Zhou, J. (2008). The effects of country-of-origin on Chinese consumers' wine purchasing behavior. Journal of Technology Management in China, 3(3), 292-306.

Ikenberry, G. J. (2018). The end of liberal international order. International Affairs, 94, 7-23.

Jaffe, E. D., \& Nebenzahl, I. (2006). National image and competitive advantage: The theory and practice of place branding. Copenhagen: Copenhagen Business School Press.

Josiassen, A., \& Harzing, A.-W. (2008). Descending from the ivory tower: Reflections on the relevance and future of country-of-origin research. European Management Review, 5(4), 264-270.

Kinra, N. (2006). The effect of country-of-origin on foreign brand names in the Indian market. Market Intelligence and Planning, 24(1), 15-30.

Klein, J., Ettenson, R., \& Morris, M. (1998). The animosity model of foreign product purchase: An empirical test in the PRC. Journal of Marketing, 62(1), 89-100.

Klein, J. G. (2002). Us versus them, or us versus everyone? Delineating consumer aversion to foreign goods. Journal of International Business Studies, 33(2), 345-363.

Lantz, G., \& Loeb, S. (1996). Country-of-origin and ethnocentrism: An analysis of Canadian and American preferences using social identity theory. Advances in Consumer Research, 23, 374-388.

Leong, S. M., Cote, J. A., Ang, S. H., Tan, S. J., Jung, K., Kau, A. K., \& Pornpitakpan, C. (2008). Understanding consumer animosity in an international crisis: Nature, antecedents, and consequences. Journal of International Business Studies, 39(6), 996-1009.

Liefeld, J. P. (2004). Consumer knowledge and use of country-of-origin information at the point of purchase. Journal of Consumer Behavior, 4(2), 85-87.

Magnusson, P., \& Westjohn, S. A. (2011). Is there a country-of-origin theory? In S. C. Jain \& D. A. Griffith (Eds.), Handbook of research in international marketing (pp. 292-316). Northampton, MA: Edward Elgar Publishing.

Maher, A. A., Clark, P., \& Maher, A. (2010). International consumer admiration and the persistence of animosity. Journal of Consumer Marketing, 27(5), 414-424.

Maheswaran, D., \& Chen, C. Y. (2009). Nation equity: Country-of-origin effects and globalization. In M. Kotabe \& K. Kelsen (Eds.), Handbook of international marketing (pp. 91-113). Thousand Oaks, CA: Sage.

Mayer, T., \& Zignago, S. (2005). Notes on CEPII's distance measures: The GeoDist database (CEPII Working Paper 2011-25).

McCallum, J. (1995). National borders matter: Canada-US regional trade patterns. American Economic Review, 85(3), 615-623.

Mika, A. (2017). Home sweet home: The homes bias in trade in the European Union (Working Paper \#2046). European Central Bank. 
Nguyen, T. D., Nguyen, T. T. M., \& Barrett, N. J. (2008). Consumer ethnocentrism, cultural sensitivity, and intention to purchase local products: Evidence from Vietnam. Journal of Consumer Behavior, 7 (1), 88-100.

Nijssen, E., \& Van Herk, H. (2005). Consumer ethnocentrism's effects on ongoing cross-border service relationships. Working Paper Series on Research in Relationship Management, Nijmegen School of Management.

Obstfeld, M., \& Rogoff, K. (2000). The six major puzzles in international macroeconomics: Is there a common cause? (Paper 7777). National Bureau of Economic Research.

Ouellet, J. F. (2005). Consumer racism and its effects on attitudes. In G. Memon \& A. R. Rao (Eds.), Advances in consumer research (Vol. 32 pp. 422-428). Duluth, MN: Association for Consumer Research.

Papadapoulos, N., Heslop, L. A., \& Bamossy, G. (1990). A comparative image analysis of domestic versus imported products. International Journal of Research in Marketing, 7(4), 283-294.

Pappu, R., Quester, P. G., \& Cooksey, R. W. (2007). Country image and consumer-based brand equity: Relationships and implications for international marketing. Journal of International Business Studies, 38(4), 726-745.

Peterson, R. A., \& Jolibert, A. J. P. (1995). A meta-analysis of country-oforigin effects. Journal of International Business Studies, 26(4), 883-900.

Pharr, J. M. (2005). Synthesizing country-or-origin research from the last decade: Is the concept still salient in an era of global brands? Journal of Marketing Theory and Practice, 13(4), 34-45.

Phau, I., \& Chao, P. (2008). Country-of-origin: State of the art review for international marketing strategy and practice. International Marketing Review, 25(4), 349-353.

Rauch, J. (2001). Business and social networks in international trade. Journal of Economic Literature, 39(4), 1177-1203.

Redding, S., \& Venables, A. J. (2000). Economic geography and international inequality, mimeo. London, England: London School of Economics.

Ricart, J. E., Enright, M. J., Ghemawat, P., Hart, S. L., \& Khanna, T. (2004). New frontiers in international strategy. Journal of International Business Studies, 35(3), 175-200.

Riefler, P., \& Diamantopoulos, A. (2007). Consumer animosity: A literature review and a reconsideration of its measurement. International Marketing Review, 24(1), 87-119.

Riefler, P., Diamantopoulos, A., \& Siguaw, J. A. (2012). Cosmopolitan consumers as a target group for segmentation. Journal of International Business Studies, 43(3), 285-305.

Sedikides, C., Wildschut, T., Routledge, C., Arndt, J., Hepper, E. G., \& Zhou, X. (2015). To nostalgize: Mixing memory with affect and desire. Advances in Experimental Social Psychology, 51, 189-273.

Shankarmahesh, M. N. (2006). Consumer ethnocentrism: An integrative review of its antecedents and consequences. International Marketing Review, 23(2), 146-172.

Sharma, P. (2011). Country of origin effects in developed and emerging markets: Exploring the contrasting roles of materialism and value consciousness. Journal of International Business Studies, 42, 285-306.

Sharma, P. (2015). Consumer ethnocentrism: Reconceptualization and cross-cultural validation. Journal of International Business Studies, 46(3), 381-389.

Sharma, S., Shimp, T. A., \& Shin, J. (1995). Consumer ethnocentrism: A test of antecedents and moderators. Journal of the Academy of Marketing Science, 23(1), 26-37.

Sheppard, B. H., Hartwick, J., \& Warshaw, P. R. (1988). The theory of reasoned action: A meta-analysis of past research with recommendations for modifications and future research. Journal of Consumer Research, 15(3), 325-343.

Shimp, T., \& Sharma, S. (1987). Consumer ethnocentrism: Construction and validation of the CETSCALE. Journal of Marketing Research, 24(3), 280-289.
Shoham, A., \& Gavish, Y. (2010). Antecedents and buying behavior consequences of consumer racism, national identification, consumer animosity, and consumer ethnocentrism. Journal of International Consumer Marketing, 28(5), 296-308.

Smith, M. B. (1992). Nationalism, ethnocentrism, and the new world order. Journal of Humanistic Psychology, 32(4), 76-91.

Steenkamp, J. B., Batra, R., \& Alden, D. L. (2003). How perceived brand globalness creates brand value. Journal of International Business Studies, 34(1), 53-65.

Steenkamp, J. B., Ter Hofstede, F., \& Wedel, M. (1999). A crossnational investigation into the individual and national cultural antecedents of consumer innovativeness. Journal of Marketing, 63(2), 55-69.

Usunier, J.-C. (2006). Relevance in business research: The case of countryof-origin research in marketing. European Management Review, 3(1), 60-73.

Usunier, J.-C., \& Cestre, G. (2008). Further considerations on the relevance of country-of-origin research. European Management Review, 3(1), 60-73.

Van Pham, K. (2006). Strategic off shoring from a decomposed COO's perspective: A cross-regional study of for product categories. Journal of the American Academy of Business, 8(2), 59-66.

Verlegh, P. W. J. (2007). Home country bias in product evaluation: The complementary roles of economic and socio-psychological motives. Journal of International Business Studies, 38(3), 361-373.

Verlegh, P. W. J., \& Steenkamp, J. B.-E. M. (1999). A review and metaanalysis of country-of-origin research. Journal of Economic Psychology, 20(5), 521-546.

Wang, C. L., \& Chen, Z. X. (2004). Consumer ethnocentrism and willingness to buy domestic products in a developing country setting: Testing moderating effects. Journal of Consumer Marketing, 21(6), 391-400.

Wang, X., \& Yang, Z. (2008). Does country-of-origin matter in the relationship between brand personality and purchase intention in emerging economies? Evidence from China's auto industry. International Marketing Review, 25(4), 458-474.

Watson, J. J., \& Wright, K. (2000). Consumer ethnocentrism and attitudes toward domestic and foreign products. European Journal of Marketing, 34(9/10), 1149-1166.

Wei, S.-J. (1996). Intra-national versus international trade: How stubborn are nations in global integration? (Working Paper 5531). National Bureau of Economic Research.

Witkowski, T. H. (1998). Consumer ethnocentrism in two emerging markets: Determinants and predictive validity. Advances in Consumer Research, 25(1), 258-263.

Yu, J. H., \& Albaum, G. (2002). Sovereignty change influences on consumer ethnocentrism and product preferences: Hong Kong revisited one year later. Journal of Business Research, 55(11), 891-899.

\section{AUTHOR BIOGRAPHY}

Yener Kandogan (yener@umich.edu) is a professor of international business at the School of Management of the University of Michigan-Flint. He is also a faculty associate at the Center for Russian, East European, and Eurasian Studies of the University of Michigan. His areas of expertise include international alliances, free trade agreements, international assignment selection, network analysis of trade, immigration and trade, political economy and trade, and role of culture/language on trade. He has more than 30 academic publications in various international business and economics journals, including Journal of International Business Studies, Journal of World Business, International Business 
Review, Journal of Business Ethics, European Journal of International Management, Thunderbird International Business Review, Applied Economics, Review of International Economics, Journal of Economic Integration, and European Journal of Political Economy. He speaks French, and is native of Turkey.
How to cite this article: Kandogan Y. Using macro crossborder trade data to better understand micro-level country of origin effects. Thunderbird Int. Bus. Rev. 2020;62:213-226. https://doi.org/10.1002/tie.22116 